JEL: Q00, Q15

Олег Стасів ${ }^{1}$ Оксана Качмар ${ }^{1}$, Оксана Вавринович ${ }^{1}$, Катерина Арабська ${ }^{2}$

${ }^{1}$ Інститут сільського господарства Карпатського регіону НААН

${ }^{2}$ Університет агробізнесу і сільського розвитку

${ }^{l}$ Украӥна

${ }^{2}$ Болгарія

\title{
ЕКОЛОГО-ЕКОНОМІЧНА ЕФЕКТИВНІСТЬ ВИРОЩУВАННЯ КУКУРУДЗИ НА ЗЕРНО В КОРОТКОРОТАЦІЙНИХ СІВОЗМІНАХ ЗАХІДНОГО РЕГІОНУ
}

Мета. Мета статті - обтрунтування економічної ефективності та екологічної дочільності вирощування кукурудзи на зерно в короткоротаційних сівозмінах Західного регіону за різних рівнів антропогенних навантажень.

Методологія / методика / підхід. Еколого-економічне оцінювання ефективності вирошування кукурудзи на зерно в короткоротаційних сівозмінах за інтенсивної та альтернативної органо-мінеральних систем удобрення виконували на основі інтерпретації інформаційного масиву даних, отриманих в умовах довготривалого експериментального модельного полігону Інституту сільського господарства Карпатського регіону впродовж 2016-2020 рр. Економічну ефективність визначали розрахунковим методом за розробленими нами технологічними картами.

Результати. Досліджено, щзо комплексне застосування мінеральних $\left(N_{120} P_{100} K_{100}\right) i$ органічних (як традиційних - гною, так $i$ альтернативних - соломи пшениці озимої стерневого попередника в сівозміні й зеленої маси післяжнивної сидеральної культури) добрив сприяє отриманню високої продуктивності зерна кукурудзи з виходом 6, 10-6,87 m/2а зернових, 8,20-9,20 m/2а кормових одиниць $i$ 0,49-0,55 m/2a перетравного протеїну. Доведено, щзо найвищі значення умовно чистого прибутку (737 дол. США/га) та окупності 1 дол. США витрат (2,0 дол. США) забезпечуються за сумісного внесення мінеральних та альтернативних органічних добрив. Установлено, щу високий умовний рівень рентабельності вирощування кукурудзи на зерно (72-104\%) формується за внесення мінеральних добрив у дозі $N_{120} P_{100} K_{100}$ на традищійних й альтернативних органічних фонах. Обтрунтовано екологостабілізачійну роль у трунтотвірних процесах органо-мінеральних удобрювальних комплексів, які пропоновані до застосування під час вирощування кукурудзи на зерно.

Оригінальність / наукова новизна. Уперше в умовах Західного регіону науково обгрунтовано еколого-економічну доцільність вирощування кукурудзи на зерно $в$ короткоротаційних сівозмінах за традиційних та альтернативних систем удобрення.

Практична цінність / значущість. Запропоновані підходи до вирощування кукурудзи на зерно в короткоротаційних сівозмінах Західного регіону забезпечують високу ї̈ зернову продуктивність на рівні виходу 6,10-6,87 m/2а зернових, 8,20-9,20 m/2а кормових $і$ 0,49$0,55 \mathrm{~m} / 2$ а перетравного протеїну, сприяють підвищенню умовного рівня рентабельності до 72-104\% за екологічно безпечного ведення сільськогосподарського виробництва.

Ключові слова: кукурудза, продуктивність, еколого-економічна ефективність, сівозміна, удобрення. 


\section{Agricultural and Resource Economics: International Scientific E-Journal}

http://are-journal.com

Oleh Stasiv ${ }^{1}$, Oksana Kachmar ${ }^{1}$, Oksana Vavrynovych ${ }^{1}$, Ekaterina Arabska ${ }^{2}$

${ }^{1}$ Institute of agriculture of Carpathian region of the NAAS

${ }^{2}$ University of Agribusiness and Rural Development

${ }^{1}$ Ukraine

${ }^{2}$ Bulgaria

\section{ECOLOGICAL AND ECONOMIC EFFICIENCY OF GROWING MAIZE FOR GRAIN IN SHORT-ROTATION CULTIVATION OF THE WESTERN REGION}

Purpose. The purpose of the article - to substantiate the economic efficiency and environmental feasibility of maize growing for grain in short-rotational cultivation in the Western region at different levels of anthropogenic loads.

Methodology / approach. Ecological and economic assessment of the efficiency of growing maize for grain in short-rotation cultivation with the help of intensive and alternative organomineral fertilization systems was carried out on the basis of the interpretation of information array of data obtained in the conditions of a long-term experimental model range of the Institute of Agriculture of the Carpathian Region during 2016-2020. The economic efficiency was determined by the calculation method according to the technological maps developed by us.

Results. It has been proved that the complex use of mineral $\left(N_{120} P_{100} K_{100}\right)$ and organic (both traditional - manure, and alternative - winter wheat straw - stubble predecessor in cultivation and green mass of post-harvest sidereal culture) fertilizers contributes to obtaining high productivity of maize grain with a yield of 6.10-6.87 t/ha of grain, 8.20-9.20 t/ha of feed units and $0.49-0.55 \mathrm{t} / \mathrm{ha}$ of digestible protein. It has been proven that the highest values of notional net profit (737 USD/ha) and payback of 1 USD of expenses (2.0 USD) are provided for joint application of mineral and alternative organic fertilizers. It has been established that a high conditional level of profitability of growing maize for grain (72-104\%) is formed for the introduction of mineral fertilizers at a dose of $N_{120} P_{100} K_{100}$ on traditional and alternative organic backgrounds. The ecological-stabilizing role of organomineral fertilizing complexes has been substantiated in soil-grain processes, proposed for use in maize growing for grain.

Originality / scientific novelty. For the first time in the conditions of the Western region, there is a scientifically substantiated ecological and economic feasibility of maize growing for grain in short-rotation cultivation with traditional and alternative fertilization systems.

Practical value / implications. The proposed approaches for growing maize for grain in short-rotation cultivation of the Western region ensure its high grain productivity at the level of yield of 6.10-6.87 t/ha of grain, 8.20-9.20 t/ha of fodder and 0.49-0.55 t/ha of digestible protein, increase the conditional level of profitability up to 72-104\% for environmentally safe agricultural production.

Key words: maize, productivity, ecological and economic efficiency, cultivation, fertilizers.

Постановка проблеми. Продовольча безпека $\epsilon$ одним із головних фундаментальних складників національної безпеки держави й базується на принципах самозабезпеченості, незалежності, фізичної й економічної доступності та якості продовольства [1]. У сучасних умовах розвитку агропромислового комплексу ринок кукурудзи є одним із найбільш важливих i вагомих сегментів продовольчої системи, посідаючи одне із провідних місць як лідер розвитку стратегічних видів продукції поряд із пшеницею, соєю, 


\section{Agricultural and Resource Economics: International Scientific E-Journal}

http://are-journal.com

соняшником, ріпаком та іншими сільськогосподарськими культурами й демонструє стабільний попит на зерно цієї культури [2].

Унаслідок змін клімату, підвищення температурного режиму, які спостерігаються в останні десятиліття, ареал вирощування кукурудзи на зерно зміщується 3 південних регіонів, які потрапили в площину ризикованого стосовно вологозабезпеченості грунтів землеробства, в зону достатнього зволоження. Спостерігається стрімка тенденція до збільшення посівних площ під цією культурою в Західному регіоні, природно-ресурсний потенціал якого став досить сприятливим для формування високих і стабільних урожаїв зерна цієї культури [3].

Аналіз виробництва зерна кукурудзи в умовах Західного регіону засвідчує, що в період від 1990 до 2019 рр. площі посіву культури зросли із 103,9 до 427,9 тис. га, тобто у 4,1 раза [4]. Найвищих значень за інтенсивністю цей показник набув у Львівській області - із 7,2 до 56,8 тис. (зростання у 7,9 раза). У структурі посівних площ господарств усіх категорій кукурудза на зерно займає 8,1\%. Якщо врахувати те, що практично вся вона вирощується в сільськогосподарських підприємствах, то перерахунок на посівну їх площу (379,0 тис га) показує 15 \% культури в структурі посівних площ [4]. Це вимагає особливої уваги до еколого-економічної оцінки агротехнологій, які повинні бути фундаментальною основою регіонального зернового аграрного виробництва й представляти собою консолідований вираз високого рівня економічної ефективності й екологічно безпечного землекористування [5; 6].

Показники економічної ефективності вирощування кукурудзи на зерно в Західному регіоні $\epsilon$ дуже контрастними [4]. Варіабельність урожайності становить 4,25 т: від 4,60 т у Чернівецькій до 8,85 т у Закарпатській області. Високим рівнем отримання зернової продукції культури відзначаються ІваноФранківська (8,73 т), Рівненська (8,71 т) та Львівська $(8,14$ т) області. Найвищі виробничі витрати на запровадження агротехнологій спостерігаються у Львівській (17299 грн/га) і Волинській (16216 грн/га), найнижчі - у Чернівецькій (11011 грн/га) областях. Собівартість вирощування кукурудзи на зерно в регіоні становить 2081-2828 грн/т. Величина прибутку різниться від 866 грн/га у Чернівецькій до 7849 грн/га в Івано-Франківській областях, мінливість рівня рентабельності перебуває в межах 13,7-52,1\%. Високою питомою вагою збиткових підприємств відзначаються Львівська (30,0\%), Чернівецька $(30,0 \%)$ і Рівненська (22,0\%) області. Така економічна ефективність виробництва кукурудзи в Західному регіоні пояснюється недосконалістю застосовуваних агротехнологій, слабкою адаптованістю їх до особливостей грунтово-кліматичних умов, неповним використанням ресурсного потенціалу. Тому впровадження науково обгрунтованих підходів до вирощування кукукурудзи на зерно для забезпечення високого рівня іiі біопродукування й економічної ефективності $\epsilon$ надзвичайно актуальною в сучасних умовах господарювання.

Аналіз останніх досліджень і публікацій. Формування економічної 
ефективності виробництва зерна кукурудзи проходить через комбіновану взаємодію рівня урожайності й затратних величин забезпечення високого рівня біопродукування культури, визначальним сегментом у структурі яких займають системи удобрення $[7 ; 8 ; 9]$. Науковими дослідженнями доведено, що найвищої продуктивності кукурудзи за одночасного збереження родючості грунтів, еколого безпечного їх функціонування можна досягнути за сумісного внесення органо-мінеральних удобрювальних комплексів [7; 10; 11; 12; 13].

Дослідженнями Z. Berzsenyi, B. Győrffy, D. Lap, проведеними в умовах довготривалих дослідів, установлено, що стабільно високу урожайність кукурудзи можна отримати за внесення гною або пожнивних решток соломи пшеничної з додаванням мінеральних добрив [7]. За даними F. Mahmood, I. Khan, U. Ashraf, T. Shahzad, S. Hussain, M. Shahid, S. Ullah, використання гною (овечого, пташиного, великої рогатої худоби) та застосування диамонійфосфату (карбаміду) i сульфату калію забезпечує зростання врожайності кукурудзи та знижує втрати поживних елементів з грунту [10].

Ученими Уганди J. Jjagwe, K. Chelimo, J. Karungi, А. J. Komakech, J. Lederer доведено ефективність внесення гною великої рогатої худоби в комбінації з 50 кг азоту (за діючою речовиною) на ріст, розвиток кукурудзи та родючість грунту [11].

Згідно 3 дослідженнями $\quad$ I. M. Uzoh, C. A. Igwe, C. B. Okebalama, O. O. Babalola, унесення пожнивних решток на фоні азотних добрив сприє підвищенню на 0,18-0,22\% азоту в грунті й на 1,16-2,74 т/га зерна кукурудзи [14].

Зниження поголів'я великої рогатої худоби, а, відтак, виробництва традиційного органічного удобрювального складника - гною (тільки у Львівській області за вирощування кукурудзи на зерно частка удобреної площі традиційною органікою становить 8,4\%) скеровує наукові дослідження на пошук альтернативних напрямів поповнення грунтового середовища органічними речовинами, обгрунтування економічних та екологічних аспектів ïх застосування й набуває надзвичайної ваги й актуальності під час розробки сучасних технологій вирощування кукурудзи на зерно й практичного їх втілення в аграрному виробництві $[7 ; 14 ; 15 ; 16 ; 17]$.

Мета статті - обгрунтування економічної ефективності та екологічної доцільності вирощування кукурудзи на зерно в короткоротаційних сівозмінах Західного регіону за різних рівнів антропогенних навантажень.

Методологія дослідження. Еколого-економічне оцінювання ефективності вирощування кукурудзи в короткоротаційних сівозмінах за традиційної та альтернативної органо-мінеральних систем удобрення виконували в умовах довготривалого стаціонарного модельного полігону, закладеного на сірому лісовому поверхнево оглеєному грунті у 2001 р. та занесеного до Реєстру довготривалих стаціонарних польових дослідів України.

Дослідження проводили в чотирипільній зерновій сівозміні 3 таким набором культур: горох - пшениця озима - кукурудза на зерно - овес у 
варіантах традиційної (із безпосереднім застосуванням під кукурудзу 40 т/га гною і $\mathrm{N}_{120} \mathrm{P}_{100} \mathrm{~K}_{100}$ мінеральних добрив) та альтернативної (сумісне внесення соломи пшениці озимої - попередника кукурудзи у сівозміні, післяжнивної сидеральної культури - редьки олійної та мінеральних добрив у дозі $\mathrm{N}_{120} \mathrm{P}_{100} \mathrm{~K}_{100}$ 3 половинним їх унесенням під посів сидерату й половинним - під культуру) системи удобрення. У середньому за сівозміну з розрахунку на гектар ріллі внесено 10 т гною $+\mathrm{N}_{51,2} \mathrm{P}_{66,2} \mathrm{~K}_{66,2}$ у традиційній і $\mathrm{N}_{33,1} \mathrm{P}_{44,3} \mathrm{~K}_{44,3}$ на фоні соломи стерневого попередника й зеленої маси сидеральної культури - в альтернативній системі удобрення. Висівали кукурудзу сорту Закарпатська жовта зубовидна 3 високим потенціалом урожайності - на рівні 9 т/га. В експерименті ми свідомо не використовували гібридів культури. Незважаючи на те, що потенціал їх урожайності на 15-35 \% більший, вони вимагають застосування високоінтенсивних технологій вирощування. Ці технології передбачають збільшення доз мінеральних добрив до $\mathrm{N}_{180-200} \mathrm{P}_{80-120} \mathrm{~K}_{160-180} \mathrm{i}$ більше. За відсутності органічних добрив, зокрема гною, це призводить до активізації мінералізаційних процесів у грунті, зниження вмісту гумусових речовин, порушення екологічної рівноваги як в агроценозах, так і прилеглих ландшафтах. Тому отримання вищого врожаю за рахунок використання гібридів не завжди є виправданим з позицій збереження родючості грунтів та екологічного стану довкілля.

Легкогідролізний азот визначали за Корнфільдом (ДСТУ 7863:2015), рухомий фосфор та обмінний калій за Кірсановим (ДСТУ 4405:2005), лабільний гумус за Сгоровим (ДСТУ 4732:2007), водорозчинний гумус за Тюріним у модифікації Сімакова (ДСТУ 4731:2007) [18; 19; 20; 21].

Урожайність кукурудзи визначали в стані технічної стиглості методом суцільного збирання облікових ділянок із перерахунком на стандартну вологість і чистоту кожного варіанта; розрахунок продуктивності культури в зернових і кормових одиницях здійснювали за виходом основної продукції 3 1 га ріллі.

Аналіз економічної ефективності вирощування кукурудзи на зерно проводили, використовуючи розрахунки затрат 3 урахуванням повної механізації робіт згідно 3 розробленими нами технологічними картами. Вартість добрив, пально-мастильних матеріалів, засобів захисту рослин, насіннєвого матеріалу взято за оптовими цінами станом на $1.06 .2020 \mathrm{p}$.

Обробку й узагальнення результатів досліджень проводили за допомогою програми Microsoft Excel. Одержані дані обробляли методом дисперсійного та кореляційного аналізу за В. О. Ушкаренко та ін. [22].

Виклад основного матеріалу дослідження. Базовою платформою, основоположним чинником аграрного виробництва $\epsilon$ високий рівень продуктивності сільськогосподарських культур [10-12]. Реалізація біопродуктивного потенціалу кукурудзи та ефективність іiі вирощування значною мірою залежить від родючості грунту й забезпеченості культури поживними речовинами [7-9; 15-17]. 
Нашими дослідженнями, проведеними впродовж 2016-2020 pp., установлено, що комплексне внесення 40 т/га гною й $\mathrm{N}_{120} \mathrm{P}_{100} \mathrm{~K}_{100}$ мінеральних добрив забезпечує найвищу врожайність зерна кукурудзи, формуючи продуктивність зерна культури на рівні 6,87 т/га зернових, 9,20 т/га кормових одиниць і 0,55 т/га перетравного протеїну (рис. 1).

Нижчі значення показників продуктивності отримано у варіантах внесення цього ж рівня мінерального живлення рослин на органічних фонах, сформованих із заораної соломи пшениці озимої, стерневого попередника кукурудзи в сівозміні й післяжнивної сидеральної культури редьки олійної. За таких умов отримано вихід 6,10 т/га зернових, 8,20 т/га кормових одиниць i 0,49 т/га перетравного протеїну.

Одним із основних показників оцінки екологічної безпеки біопродукування сільськогосподарських культур, стабільності функціонування грунтових систем і режимів та ефективності ведення землеробства в цілому $є$ баланс основних елементів живлення рослин [13]. Особливої ваги цей фактор набуває за умов інтенсифікації сільськогосподарського виробництва, виступаючи індикатором попередження небезпеки виникнення деградаційної вразливості грунтів й екологічної дестабілізації довкілля [6; 8].

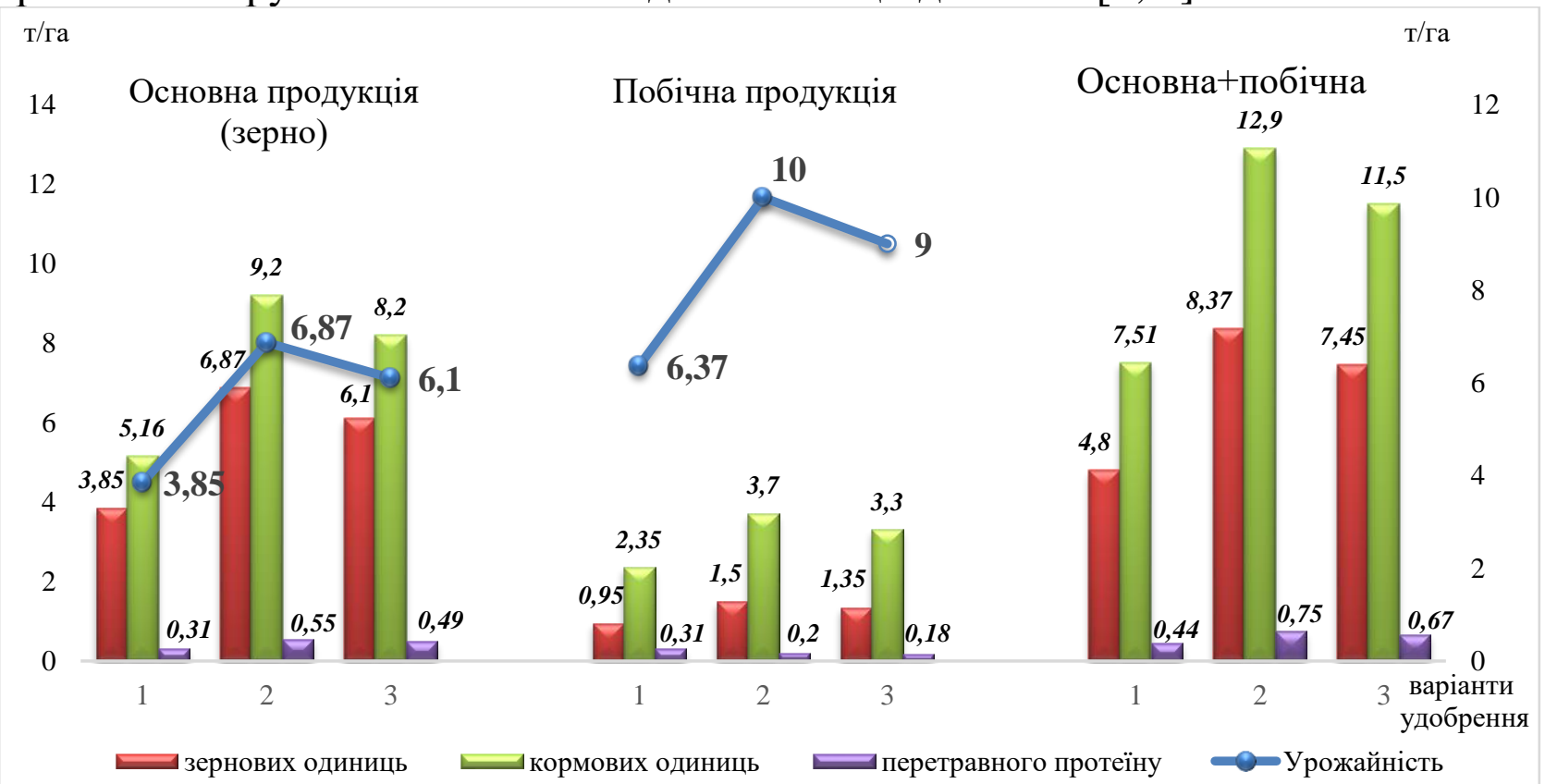

Рис. 1. Продуктивність кукурудзи в короткоротаційних сівозмінах Західного регіону України за різних рівнів антропогенних навантажень

Примітка. 1 - контроль; 2 - гній, 40 т/га $+\mathrm{N}_{120} \mathrm{P}_{100} \mathrm{~K}_{100} ; 3$ - сидерат $+\mathrm{N}_{120} \mathrm{P}_{100} \mathrm{~K}_{100}+$ побічна продукція.

Джерело: розраховано на основі власних експериментальних даних.

Застосування органо-мінеральних удобрювальних комплексів під кукурудзу на зерно в короткоротаційній зерновій сівозміні забезпечувало додатні значення показників балансу основних елементів живлення (рис. 2).

Вищі значення балансу азоту (+140 кг/га), фосфору (+138 кг/га) й калію (+161 кг/га) формувалися за сумісного внесення під кукурудзу на зерно 40 т/га гною й $\mathrm{N}_{120} \mathrm{P}_{100} \mathrm{~K}_{100}$ мінеральних добрив. Застосування цього ж рівня 
мінерального живлення на альтернативних органічних фонах забезпечувало показники балансу на рівні +74 кг/га азоту, +78 кг/га фосфору й +13 кг/га калію.

Важливим показником екологічної безпеки агротехнологій $\epsilon$ рухомі (лабільні й водорозчинні) гумусові речовини, які внаслідок стабілізаційних процесів поповнюють загальні запаси гумусу в грунті, а за переважання мінералізаційних трансформацій виступають джерелом поживних елементів i забезпечують високий рівень біопродукування сільськогосподарських культур [23].

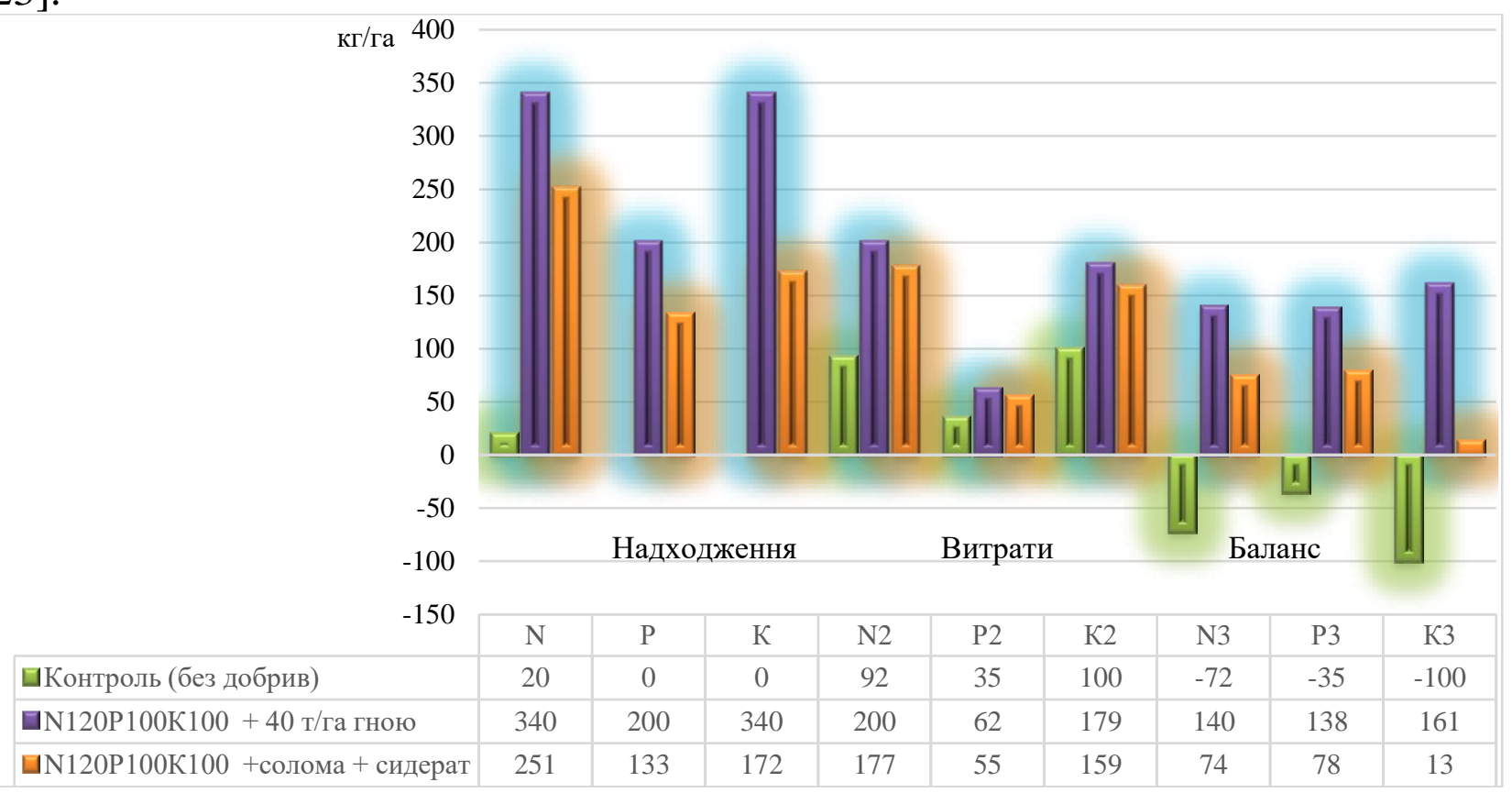

Рис. 2. Баланс основних елементів живлення, кг/га

Примітка. N, P, K - надходження азоту, фосфору та калію; N2, P2, K2 - витрати азоту, фосфору та калію; N3, P3, K3 - баланс азоту, фосфору та калію.

Джерело: розраховано на основі власних експериментальних даних.

Дослідженнями встановлено, що сумісне використання гною 40 т/га i мінеральних добрив у дозі $\mathrm{N}_{120} \mathrm{P}_{100} \mathrm{~K}_{100}$ під кукурудзу сприяло отриманню найвищих значень лабільного й водорозчинного гумусу - 574,26 i 22,65 мг/100 г грунту. Застосування альтернативи гною на цих же мінеральних фонах забезпечило нижчий рівень їх накопичення в грунті (відповідно 493,28 i 20,95 мг/100 г). До кінця вегетації культури ці показники знижувалися як на удобрених, так і на неудобрених варіантах унаслідок мінералізаційних процесів i використання продуктів їх розпаду для живлення рослин. Однак, у час повної стиглості культури на органо-мінеральних фонах кількість лабільних i водорозчинних гумусових речовин залишалася вищою порівняно до неудобреного варіанта у фазі сходів кукурудзи. Це свідчить про те, що значна частина рухомих гумусових речовин, яка утворилася з удобрення, залишається в грунтовому середовищі й може слугувати джерелом для поповнення загального гумусу - інтегрального показника екологічної стабільності грунту (рис. 3).

Важливим є те, що в умовах недостатньої кількості традиційної органіки гною великої рогатої худоби, у системах удобрення може бути використано 
побічну продукцію рослинництва, зокрема солому пшениці озимої та зелену масу післяжнивних сидеральних культур, які в комплексі 3 мінеральними добривами забезпечують вагомий рівень продуктивності кукурудзи на зерно та сприяють стабілізації екологічної рівноваги в грунті.

У сучасних умовах рівноважливим завданням поруч із отриманням високого рівня продуктивності сільськогосподарських культур, дотриманням умов екологічно безпечного ведення аграрного виробництва, постає аналіз його економічної ефективності [5; 6; 9].
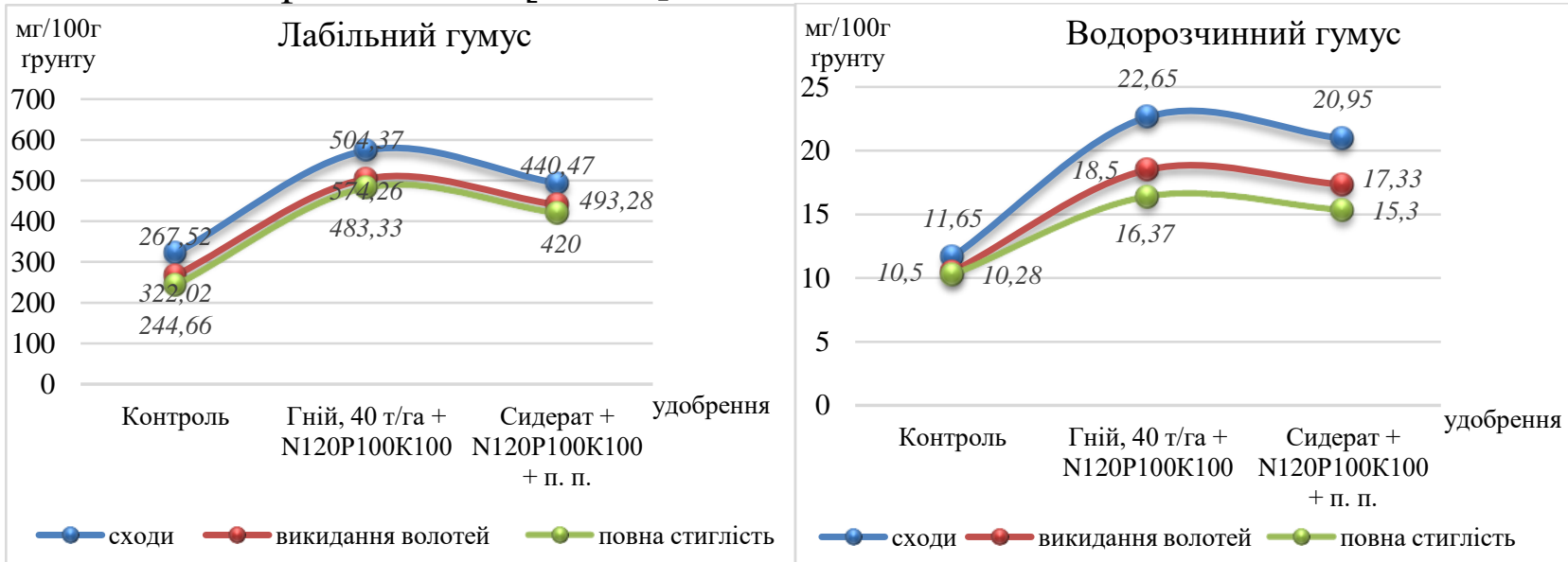

Рис. 3. Динаміка лабільного та водорозчинного гумусу під кукурудзою на зерно в короткоротаційних сівозмінах Західного регіону України залежно від удобрення, мг/100 г грунту

Примітка. П.п. - побічна продукція.

Джерело: розраховано на основі власних експериментальних даних.

Для розрахунку економічної ефективності вирощування кукурудзи на зерно залежно від рівня удобрення в короткоротаційній зерновій сівозміні визначали вартість валової продукції 31 га, виробничі витрати на 1 га, собівартість 1 т зерна, умовно чистий прибуток з 1 га, рівень рентабельності й окупність витрат на виробництво.

До статті витрат на отримання урожаю включено вартість насіння, пальномастильних матеріалів, добрив, пестицидів, витрати на заробітну плату, а також амортизаційні, загальногосподарські, накладні витрати.

Аналіз витрат показав, що найнижчими вони були на контрольних (неудобрених) варіантах і перебували на рівні 298 дол. США/га. Застосування альтернативного удобрення з унесенням мінеральних добрив у дозі $\mathrm{N}_{120} \mathrm{P}_{100} \mathrm{~K}_{100}$ на фоні заореної соломи пшениці озимої та післяжнивної редьки олійної збільшувало цей показник до 711 дол. США/га. Унесення цього ж рівня мінерального живлення рослин у поєднанні 3 традиційним органічним складником органо-мінеральних систем - гноєм великої рогатої худоби формувало найвищий розмір витрат - 940 дол. США/га. За внесення гною витратні статті значною мірою залежать від відстані його транспортування. Наші дослідження проводилися за 0,9-1,2 км від ферми утримання великої рогатої худоби та місця складування й зберігання гною (Державне підприємство «Дослідне господарство «Оброшине», яке є експериментальною 
базою Інституту сільського господарства Карпатського регіону НААН). Перевезення гною здійснювали розкидачами, без перевантаження. Тому вартість транспортування й унесення традиційного органічного удобрення в наших дослідженнях $є$ невисокою (ми ii аналізували й ураховували в статті витрат). У виробничих умовах, якщо товаровиробник не займається тваринництвом і немає цієї органіки, закупівля й перевезення гною більше як на 50 км є економічно не вигідною й не практикується, тому ми в наших дослідженнях запропонували альтернативу у вигляді соломи та післяжнивної сидерації й зробили відповідні розрахунки витрат. Ціна гною визначена за його якісним складом і зіставлена із ціною мінеральних добрив із таким же співвідношенням NPK і $€$ розрахунковою між ДП «ДГ «Оброшине» та Інститутом сільського господарства Карпатського регіону НААН. Закупівлю мінеральних добрив проводять за тендерними договорами й транспортування до складу інституту здійснюється за рахунок постачальника (вони включені у вартість добрив). Вивіз на поле проводили розкидачем РУМ. Відстань зі складських приміщень - 0,5 км (витрати враховано в розрахунку витрат). У варіанті традиційної органо-мінеральної системи удобрення (гній $40 \mathrm{~T} /$ га + $\mathrm{N}_{120} \mathrm{P}_{100} \mathrm{~K}_{100}$ ) використовували гній у нормі 40 т/га за ціною 5,72 дол. США/т, сума витрат становила близько 229 дол. (40 т х 5,72 дол. США). Із мінеральних добрив у дослідженнях застосовували - нітроамофоску $16 \%$ діючої речовини (д. р.) й аміачнау селітру 34 \% д. р. за ціною відповідно 50,5 і 39,7 дол. США/ц. Зважаючи на норму $\mathrm{N}_{120} \mathrm{P}_{100} \mathrm{~K}_{100}$, фізична вага комплексного добрива становила 6,25 ц, аміачної селітри - 0,6 ц, сума витрат становила за нітроамофоскою близько 316 дол. США (50,5 дол. США х 6,25 ц), азотного удобрення близько 24 дол. США (39,7 дол. США х 0,6 ц).

У складі та структурі витрат (табл. 1) найбільш вагомими складниками були вартість добрив (на органо-мінеральних фонах вони становили 382 569 дол. США/га, що дорівнює 54-61\% від загальних витрат) і пальномастильних матеріалів (126-159 дол. США/га, відповідно 17-18 \%).

Таблиия 1

Розрахунок витрат на вирощування кукурудзи на зерно в короткоротаційних сівозмінах Західного регіону України за різних рівнів удобрення, дол. США/га

\begin{tabular}{|c|c|c|c|c|c|c|c|c|c|}
\hline Варіанти удобрення & 氙 & 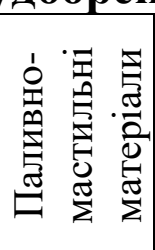 & 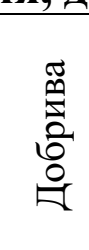 & 声 & 竞 & 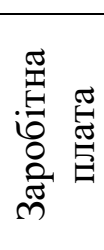 & 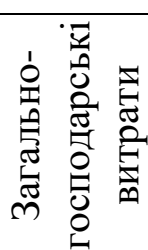 & 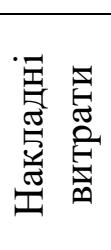 & $\begin{array}{l}\Sigma \\
0 \\
\tilde{D} \\
\tilde{D}\end{array}$ \\
\hline Контроль & 14 & 109 & 0 & 51 & 28 & 75 & 10 & 11 & 298 \\
\hline $\begin{array}{l}\text { Гній, } 40 \text { т/га + } \\
\mathrm{N}_{120} \mathrm{P}_{100} \mathrm{~K}_{100}\end{array}$ & 14 & 159 & 569 & 51 & 35 & 84 & 15 & 13 & 940 \\
\hline $\begin{array}{l}\text { Сидерат }+\mathrm{N}_{120} \mathrm{P}_{100} \mathrm{~K}_{100} \\
+ \text { побічна продукція }\end{array}$ & 14 & 126 & 382 & 51 & 32 & 80 & 13 & 12 & 711 \\
\hline
\end{tabular}

Джерело: розраховано на основі власних технологічних карт.

Згідно $з$ проведеною оцінкою економічної ефективності вирощування 
кукурудзи на зерно встановлено, що найвищі умовно чистий прибуток (737 дол. США/га) та окупність 1 дол. США витрат (2,0 дол. США) отримано за комплексного внесення мінеральних добрив, соломи стерневого попередника та зеленої маси сидеральної піляжнивної редьки олійної (табл. 2).

Сумісне застосування мінеральних добрив у цій же дозі та 40 т/га гною забезпечувало отримання умовно чистого прибутку на рівні 678 дол. США/га та окупність 1 дол. США витрат - 1,7 дол. США.

Табличя 2

Розрахунок економічної ефективності вирощування кукурудзи на зерно в короткоротаційних сівозмінах Західного регіону України за різних рівнів удобрення

\begin{tabular}{|l|c|c|c|c|c|c|}
\hline \multicolumn{1}{|c|}{$\begin{array}{c}\text { Варіанти } \\
\text { удобення }\end{array}$} & $\begin{array}{c}\text { Вартість } \\
\text { урожаю, } \\
\text { дол. } \\
\text { США/га }\end{array}$ & $\begin{array}{c}\text { Витрати } \\
\text { на } \\
\text { урожай, } \\
\text { дол. } \\
\text { США/га }\end{array}$ & $\begin{array}{c}\text { Собівар- } \\
\text { тість 1 т } \\
\text { зерна, } \\
\text { дол. } \\
\text { США }\end{array}$ & $\begin{array}{c}\text { Умовно } \\
\text { чистий } \\
\text { приуток, } \\
\text { дол. } \\
\text { США/га }\end{array}$ & $\begin{array}{c}\text { Окупність } \\
\text { дол. } \\
\text { США } \\
\text { витрат, } \\
\text { дол. США }\end{array}$ & $\begin{array}{c}\text { Умовний } \\
\text { рівень } \\
\text { рентабель- } \\
\text { ності, \% }\end{array}$ \\
\hline Контроль & 817 & 298 & 77 & 519 & 2,7 & 174 \\
\hline $\begin{array}{l}\text { Гній, } 40 \text { т/га + } \\
\mathrm{N}_{120} \mathrm{P}_{100} \mathrm{~K}_{100}\end{array}$ & 1618 & 940 & 137 & 678 & 1,7 & 72 \\
\hline $\begin{array}{l}\text { Сидерат + } \\
\mathrm{N}_{120} \mathrm{P}_{100} \mathrm{~K}_{100}+ \\
\text { побічна продукція }\end{array}$ & 1448 & 711 & 116 & 737 & 2,0 & 104 \\
\hline
\end{tabular}

Джерело: розраховано на основі власних технологічних карт.

Рентабельність це один із основних показників економічної ефективності виробництва, який дозволяє оцінити формування прибутку. У наших дослідженнях за комплексного внесення органічних i мінеральних добрив значення умовного рівня рентабельності були високими й формувалися на рівні 72-104\%. У контрольному варіанті, незважаючи на те, що умовно чистий прибуток порівняно з ділянками, на яких уносили мінеральні добрива в дозі $\mathrm{N}_{120} \mathrm{P}_{100} \mathrm{~K}_{100}$ на традиційних й альтернативних органічних фонах був на $31-42 \%$ нижчим, умовний рівень рентабельності становить 174 \%. Це пояснюється зокрема тим, що в статтях витрат на отримання врожаю на контрольному варіанті відсутня вартість органічних і мінеральних добрив.

Для виявлення зв'язку, оцінки його напряму й інтенсивності нами проведено парний лінійний кореляційний аналіз між показниками продуктивності (вихід зернових, який у наших розрахунках співмірний із рівнем урожайності, кормових одиниць, перетравного протеїну) кукурудзи та отриманим умовним прибутком, а також умовним прибутком й умовним рівнем рентабельності - визначальними чинниками економічної ефективності агротехнологій (табл. 3). Обсяг вибірки $n=90$ (взято ознаки за П'ять років досліджень (щорічні) за трифакторної повторності експерименту й шестикратному відбору зразків.

Установлено наявність функціонального лінійного зв'язку між виходом зернових (X, т/га) і прибутком (Y, дол. США/га) та кормових одиниць (X, т/га) та умовним прибутком (Y, дол. США/га) (значення лінійного коефіцієнта 
кореляції $(r)$ були рівними 1,000). Між виходом перетравного протеїну $(\mathrm{X}, \mathrm{T} / г \mathrm{a})$ й умовним прибутком (Y, дол. США/га) кореляційна залежність була високою, змінювалася залежно від варіантів досліду й більших значень набувала під час застосування органо-мінеральньного удобрення $(r=0,995-0,996) \quad$ зі стандартною похибкою коефіцієнта кореляції $\mathrm{s}_{\mathrm{r}}=0,0106-0,0095$, що свідчить про його високу надійність. Аналіз критеріїв істотності коефіцієнта кореляції на основі $t$-критерію Стьюдента показав, що на удобрених варіантах фактичні його значення $(93,86-104,84)$ як за $5 \%(1,98)$, так і за більш строгого підходу $1 \%(2,63)$ рівні значущості були вищими за теоретичні, що підтверджує достовірність кореляційного зв'язку.

Проведення кореляційного аналізу між умовним рівнем рентабельності й умовним прибутком показало високу залежність між ними 3 варіабельністю лінійного коефіцієнта кореляції від 1,000 на удобрених варіантах до 0,964 на контролі з критерієм істотності коефіцієнта кореляції останнього 34,06, що також перевищує теоретичну величину як за одно-, так і п'ятивідсоткового рівня значущості й доводить достовірність кореляційного зв'язку.

Таблиия 3

Кореляційно-регресійний аналіз ефективності вирощування кукурудзи на зерно в короткоротаційних сівозмінах Західного регіону України за різних рівнів удобрення, 2016-2020 pp.

\begin{tabular}{|c|c|c|c|c|}
\hline Варіанти удобрення & $\begin{array}{l}\text { Коефіцієнт } \\
\text { кореляції, } \\
\text { r }\end{array}$ & $\begin{array}{c}\text { Коефіцієнт } \\
\text { детермінації, } \\
\text { dxy }_{\text {xy }}\end{array}$ & $\begin{array}{c}\text { Похибка } \\
\text { коефіцієнта } \\
\text { кореляції, sr }\end{array}$ & Рівняння регресії \\
\hline \multicolumn{5}{|c|}{ Залежність прибутку (Y, дол. США/га) від виходу зернових одиниць (X, т/га) } \\
\hline Контроль & 1,000 & 1,000 & 0 & $\mathrm{Y}=278,79 \mathrm{X}-297$ \\
\hline Гній, 40 т/га $+\mathrm{N}_{12}$ & 1,000 & 1,000 & 0 & $Y=279,25 X-942$ \\
\hline Сидерат + п. п. + $\mathrm{N}_{120} \mathrm{P}_{100} \mathrm{~K}_{100}$ & 1,000 & 100,0 & 0 & $\mathrm{Y}=279,50 \mathrm{X}-715$ \\
\hline \multicolumn{5}{|c|}{ Залежність прибутку (Y, дол. США/га) від виходу кормових одиниць (X, т/га) } \\
\hline Контроль & 1,000 & 1,000 & 0 & $Y=208,08 X-297$ \\
\hline Гній, 40 т/га + N120 & 1,000 & 1,000 & 0 & $\mathrm{Y}=2$ \\
\hline Сидерат + п. п. + $\mathrm{N}_{120} \mathrm{P}_{100} \mathrm{~K}_{100}$ & 1,000 & 1,000 & 0 & $\mathrm{Y}=208,58 \mathrm{X}-715$ \\
\hline \multicolumn{5}{|c|}{ Залежність прибутку (Y, дол. США/га) від виходу перетравного протеїну (X, т/га) } \\
\hline Контроль & 0,926 & 0,857 & 0,0398 & $\mathrm{Y}=3793,40 \mathrm{X}-378$ \\
\hline Гній, 40 т/га $+\mathrm{N}_{120} \mathrm{P}_{100} \mathrm{~K}_{100}$ & 0,995 & 0,989 & 0,0106 & $\mathrm{X}-809$ \\
\hline Сидерат + п. п. + $\mathrm{N}_{120} \mathrm{P}_{100} \mathrm{~K}_{100}$ & 0,996 & 0,991 & 0,0095 & $Y=3588,94 X-762$ \\
\hline \multicolumn{5}{|c|}{ Залежність рівня рентабельності (X, \%) від прибутку (Y, дол. США/га) } \\
\hline Контроль & 0,964 & 0,930 & 0,0283 & $\mathrm{Y}=3,35 \mathrm{X}-109$ \\
\hline Гній, 40 т/га $+\mathrm{N}_{120} \mathrm{P}_{100} \mathrm{~K}_{100}$ & 1,000 & 0,999 & 0 & $Y=9,28 X+14,7$ \\
\hline Сидерат + п. п. + $\mathrm{N}_{120} \mathrm{P}_{100} \mathrm{~K}_{100}$ & 1,000 & 0,100 & 0 & $\mathrm{Y}=7,07 \mathrm{X}+6,84$ \\
\hline
\end{tabular}

Джерело: розраховано на основі власних даних.

Нами також проведено парний лінійний кореляційний аналіз між показниками рівня внесення добрив (X, кг д. р.) й урожайністю, та рівнем внесення добрив й отриманим умовним прибутком (Y, дол. США/га). Обсяг вибірки, знову-таки, становив $n=90$. Установлено, що під час застосування органо-мінеральних систем (за сумарного внесення елементів живлення на рівні 680-889 кг д. р.) кореляційна залежність між удобренням (X, кг д. р.) та 
врожайністю зерна кукурудзи (Y, т/га) змінювалася від сильної $(r=0,724)$ за коефіцієнта детермінації $\mathrm{d}_{\mathrm{xy}}=0,524$ і стандартної похибки коефіцієнта кореляції $\mathrm{s}_{\mathrm{r}}=0,0735$ за традиційної органічної складової до значної $(r=0,694)$ за $\mathrm{d}_{\mathrm{xy}}=48,1$ i $\mathrm{s}_{\mathrm{r}}=0,0767$ - за альтернативної системи. Подібні залежності здобуто між удобренням (X, кг д. р.) й отриманим умовним прибутком (Y, дол. США/га): коефіцієнт кореляції був на рівні $r=0,708-0,683$ за стандартної похибки $\mathrm{s}_{\mathrm{r}}=0,0753-0,0779$. Критерій істотності був у межах 9,40-8,77, що перевищує теоретичні значення як за $1 \%$, так і за $5 \%$ рівня значущості й підтверджує достовірність кореляційного зв’язку.

На основі підтверджених кореляційним аналізом взаємозв'язків між досліджуваними показниками нами визначено рівняння кількісної лінійної залежності із застосуванням регресійного аналізу (наведено в табл. 3).

У наших дослідженнях проведено також множинний кореляційний аналіз, де результативними ознаками виступали основні показники економічної ефективності вирощування кукурудзи на зерно - розмір умовного прибутку (Y, дол. США/га) та умовний рівень рентабельності (Y,\%), а факторними інтегральні чинники впливу на них - урожайність зерна кукурудзи $(X, \mathrm{~T} / г \mathrm{a}) \mathrm{i}$ кількість унесених елементів живлення 3 добривами (Z, кг д. р.). Математикостатистичним аналізом установлено високі значення множинного коефіцієнта кореляції як між розміром умовного прибутку й урожайністю культури та удобренням, так і рівнем рентабельності й цими ж факторними величинами $\left(R_{y . x z}=0,999\right)$. Значущість множинної кореляції за $\mathrm{F}$ (фактичним) критерієм становила 49,2, що перевищувало значення $\mathrm{F}$ (теоретичного) як за 5 \% $(3,09)$, так і за $1 \%(4,82)$ рівнів значущості, що слугує статистичним підтвердженням достовірності кореляційного зв'язку.

Для підвищення точності прогнозів економічної ефективності вирощування кукурудзи на зерно нами розраховано й побудовано багатофакторні моделі. У моделях множинної регресії нами досліджено залежність між умовним прибутком (Y, дол. США/га) у традиційній системі удобрення за використання гною як органічного складника, урожайністю зерна кукурудзи $(\mathrm{X}, \mathrm{T} / г \mathrm{r})$ і рівнем внесення добрив ( $\mathrm{Z}$, кг д. р.), яка описується рівнянням:

$$
\mathrm{Y}=-2054+279,25 \mathrm{X}+1,253 \mathrm{Z}
$$

а також цими ж показниками за альтернативної системи удобрення:

$$
\mathrm{Y}=-1201+279,50 \mathrm{X}+0,716 \mathrm{Z}
$$

Також здійснено множинний регресійний аналіз залежності умовного рівня рентабельності (Y, \%) від урожайності зерна кукурудзи $(\mathrm{X}, \mathrm{T} / г \mathrm{a})$ і рівня внесення добрив $(\mathrm{Z}$, кг д. р.) за традиційної й альтернативної систем удобрення. Резульати аналізу відображають рівняння:

$$
\begin{gathered}
Y=-1215+30,08 X+1,253 Z \\
Y=-589+39,51 X+0,716 Z
\end{gathered}
$$

Побудовані економетричні моделі ми перевірили на адекватність реальним залежностям. За допомогою тесту Дарбіна-Уотсона нами проаналізовано 


\section{Agricultural and Resource Economics: International Scientific E-Journal}

http://are-journal.com

наявність автокореляції залишків. Математичним аналізом установлено, що критерій Дарбіна-Уотсона в наших розрахунках рівний 2,011 (DW = 2,011). Його значення потрапляє в проміжок DWu - 4-DWu у межах інтервалу [0; 4]. Отже, залишки є випадковими величинами, тобто вони є не автокорельовані. Таким чином, автокореляція залишків відсутня.

Усі отримані нами моделі у вигляді як лінійних однофакторних, так і множинних рівнянь регресії, слугують економіко-математичними патернами й дають можливість розробляти прогнозні схеми та приймати управлінські рішення щодо підвищення економічної ефективності вирощування кукурудзи на зерно в короткоротаційних сівозмінах Західного регіону України.

Висновки. У результаті дослідження зроблено такі висновки:

1. Комплексне застосування мінеральних й органічних (як традиційних, так i альтернативних) добрив забезпечує високу продуктивність зерна кукурудзи 3 отриманням 6,10-6,87 т/га зернових, 8,20-9,20 т/га кормових i 0,49-0,55 т/га перетравного протеїну.

2. Органо-мінеральні удобрювальні комплекси сприяють екологічно стабільному функціонуванню грунтових систем, формуючи позитивні показники балансу основних елементів живлення рослин i забезпечуючи процеси гумусонакопичення шляхом поповненя грунтового середовища лабільними гумусними речовинами.

3. В умовах недостатньої кількості гною великої рогатої худоби в системах удобрення може бути використано побічну продукцію рослинництва, зокрема солому пшениці озимої та зелену масу післяжнивних сидеральних культур, які в комплексі 3 мінеральними добривами забезпечують вагомий рівень продуктивності кукурудзи на зерно та сприяють стабілізації екологічної рівноваги в грунті.

4. Найвищі значення умовно чистого прибутку (737 дол. США/га) та окупності 1 дол. США витрат (2,0 дол. США) забезпечуються за комплексного внесення мінеральних добрив у дозі $\mathrm{N}_{120} \mathrm{P}_{100} \mathrm{~K}_{100}$, соломи пшениці озимої як попередника кукурудзи у сівозміні й зеленої маси сидеральної піляжнивної редьки олійної.

5. Сумісне застосування мінеральних добрив $\left(\mathrm{N}_{120} \mathrm{P}_{100} \mathrm{~K}_{100}\right)$ та 40 т/га гною формують значення умовно чистого прибутку на рівні 678 дол. США/га й окупність 1 дол. США витрат - 1,7 дол. США.

6. Високий умовний рівень рентабельності вирощування кукурудзи на зерно (72-104 \%) забезпечується за сумісного внесення мінеральних добрив у дозі $\mathrm{N}_{120} \mathrm{P}_{100} \mathrm{~K}_{100}$ на традиційних й альтернативних органічних фонах.

7. За вирощування кукурудзи на зерно на органо-мінеральних фонах живлення в короткоротаційній сівозміні спостерігається висока кореляційна залежність прибутку від параметрів виходу зернових, кормових одиниць $(r=1,000)$, перетравного протеїну $(r=0,995-0,996)$.

8. Кореляційна залежність між рівнем внесення добрив й урожайністю та рівнем внесення добрив й отриманим прибутком оцінюється як сильна за 


\section{Agricultural and Resource Economics: International Scientific E-Journal}

http://are-journal.com

традиційної та значна за альтернативної системи удобрення 3 математично підтвердженою достовірністю кореляційного зв’язку.

Отримані результати досліджень можуть бути використані товаровиробниками сільськогосподарської продукції як базові засади під час вирощування кукурудзи на зерно. Актуальним і перспективним напрямом досліджень є обгрунтування економічної ефективності вирощування кукурудзи на зерно за екологічно безпечного ведення аграрного виробництва.

\section{Список використаних джерел}

1. Настич В. Г. Продовольча безпека як складова національної безпеки України. Вісник Бердянського університету менеджменту $i$ бізнесу. 2013. № 3(23). С. 43-48.

2. Месель-Веселяк В. Я. Виробництво зернових культур в Україні: потенційні можливості. Економіка АПК. 2018. № 5. С. 5-14.

3. Камінський В. Ф., Сайко В. Ф. Стратегія оптимізації використання земельних ресурсів в агропромисловому виробництві України в контексті світового стабільного розвитку. Вісник аграрної науки. 2014. № 3. С. 5-10.

4. Сільське господарство України 2019: стат. збірник. Київ: Державна служба статистики України, 2020. 230 с.

5. Snapp S. S., Grabowski P., Chikowo R., Smith A., Anders E., Sirrine D., Bekunda M. Maize yield and profitability tradeoffs with social, human and environmental performance: is sustainable intensification feasible? Agricultural Systems. 2018. Vol. 162. Pp. 77-88. https://doi.org/10.1016/j.agsy.2018.01.012.

6. Sandhu H., Scialabba N., Warner C., Behzadnejad F., Keohane K., Houston R., Fujiwara D. Evaluating the holistic costs and benefits of corn production systems in Minnesota, US. Scientific reports. 2020. Vol.10(1). Pp. 1-12. https://doi.org/10.1038/s41598-020-60826-5.

7. Berzsenyi Z., Györffy B., Lap D. Effect of crop rotation and fertilisation on maize and wheat yields and yield stability in a long-term experiment. European Journal of Agronomy. 2000. Vol. 13(2-3). Pp. 225-244. https://doi.org/10.1016/S1161-0301(00)00076-9.

8. Theriault V., Smale M., Haider H. Economic incentives to use fertilizer on maize under differing agro-ecological conditions in Burkina Faso. Food Security. 2018. Vol. 10(5). Pp. 1263-1277. https://doi.org/10.1007/s12571-018-0842-z.

9. Bykin A. V., Bykina N., Bordyuzha N., Ivanytska A. The economic efficiency of the fertilizers application under agricultural crops for different soil tillage. Рослинництво та грунтознавство. 2019. Вип. 10(2). С. 62-69. https://doi.org/10.31548/agr2019.02.062.

10. Mahmood F., Khan I., Ashraf U., Shahzad T., Hussain S., Shahid M., Ullah S. Effects of organic and inorganic manures on maize and their residual impact on soil physico-chemical properties. Journal of soil science and plant nutrition. 2017. Vol. 17(1). Pp. 22-32. https://doi.org/10.4067/S0718-95162017005000002.

11. Jjagwe J., Chelimo K., Karungi J., Komakech A. J., Lederer J. Comparative performance of organic fertilizers in maize (Zea mays L.) growth, yield, and 
Agricultural and Resource Economics: International Scientific E-Journal http://are-journal.com

\begin{tabular}{llllll}
\hline economic & results. & Agronomy. & 2020. & Vol. 10(1). & 69.
\end{tabular} https://doi.org/10.3390/agronomy10010069.

12. Poruțiu A., Arion F., Mureșan I., Fărcaș R., Sălăgean T., Moldovan L. Economic optimization of the fertilization system on corn crops on a representative soil in the Transylvanian plain. Bulletin of University of Agricultural Sciences and Veterinary Medicine Cluj-Napoca. Horticulture. 2016. Vol. 73(1). Pp. 52-58. https://doi.org/10.15835/buasvmen-hort:11601.

13. Adamtey N., Musyoka M., Zundel C. et al. Productivity, profitability and partial nutrient balance in maize-based conventional and organic farming systems in Kenya. Agriculture, Ecosystems \& Environment. 2016. Vol. 235. Pp. 61-79. https://doi.org/10.1016/j.agee.2016.10.001.

14. Uzoh I. M., Igwe C. A., Okebalama C. B., Babalola O. O. Legume-maize rotation effect on maize productivity and soil fertility parameters under selected agronomic practices in a sandy loam soil. Scientific Reports. 2019. No.9. 8539. https://doi.org/10.1038/s41598-019-43679-5.

15. Демиденко О., Шаповал I., Бойко П., Величко В. Параметри продуктивності та структура фітомаси різноротаційних сівозмін Лісостепу України. Вісник аграрної науки. 2018. № 5. С. 54-62. https://doi.org/10.31073/agrovisnyk201805-09.

16. Diallo L., Qing-jun C., Zhen-ming Y., Jin-hu C., Dafaalla T. Effects of various doses of mineral fertilizers (NPKS and Urea) on yield and economic profitability of new varieties of Zea mays L. in Faranah, Guinea. Journal of Northeast Agricultural University. 2016. Vol. 23(1). Pp. 1-8. https://doi.org/10.1016/S1006-8104(16)30025-3.

17. Jarecki M., Grant B., Smith W., Deen B., Drury C., Vander Zaag A., Wagner-Riddle C. Long-term trends in corn yields and soil carbon under diversified crop rotations. Journal of environmental quality. 2018. Vol. 47(4). Pp. 635-643. https://doi.org/10.2134/jeq2017.08.0317.

18. ДСТУ 7863:2015. Якість грунту. Визначення легкогідролізного азоту методом Корнфілда. [Чинний від 2016-07-01]. Київ: УкрНДНЦ, 2016. 9 с. URL: http://online.budstandart.com/ua/catalog/doc-page.html?id_doc=62745.

19. ДСТУ 4405: 2005. Якість грунту. Визначання рухомих сполук фосфору і калію за методом Кірсанова в модифікації ННЦ ІГА. [Чинний від 2006-07-01]. Київ: Держспоживстандарт України. $2006 . \quad 18$ с. URL: http://online.budstandart.com/ua/catalog/doc-page?id_doc=60252.

20. ДСТУ 4732:2007. Якість грунту. Методи визначення лабільної органічної речовини. [Чинний від 2008-01-01]. Київ: Держспоживстандарт України, 2007. 11 с. URL: http://online.budstandart.com/ua/catalog/docpage.html?id_doc=72886/.

21. ДСТУ 4731:2007. Якість грунту. Методи визначення водорозчинної органічної речовини. [Чинний від 2008-01-01]. Київ: Держспоживстандарт України, 2007. $11 \mathrm{c.}$

22. Ушкаренко В. О., Вожегова Р. А.,, Голобородько С. П., Коковіхін С. В. 


\section{Agricultural and Resource Economics: International Scientific E-Journal}

http://are-journal.com

Статистичний аналіз результатів польових дослідів у землеробстві. Херсон: Айлант, 2013. 378 с.

23. Качмар О., Вавринович О., Дубицька А., Дубицький О., Щерба М. Вплив систем удобрення на динаміку нестабільних гумусових речовин в короткоротаційних сівозмінах. Вісник Львівського національного аграрного університету. Агрономія. $2019 . \quad$ № $23 . \quad$ C. 234-237. https://doi.org/10.31734/agronomy2019.01.234.

\section{References}

1. Nastych V. G. (2013), Food security as a component of national security of Ukraine. Bulletin of Berdyansk University of Management and Business, no. 3(23), pp. 43-48.

2. Mesel-Veselyak, V. Ya. (2018), Production of grain crops in Ukraine: potential opportunities. Ekonomika APK, no. 5, pp. 5-14.

3. Kaminsky, V. F. and Saiko, V. F. (2014), Strategy for optimizing the use of land resources in agro-industrial production of Ukraine in the context of global sustainable development. Bulletin of Agricultural Science, no. 3, pp. 5-10.

4. State Statistics Service of Ukraine (2020), Sil's'ke hospodarstvo Ukrainy 2019. Statystychnyj zbirnyk [Agriculture of Ukraine 2019. Statistical yearbook], State Statistics Service of Ukraine, Kyiv, Ukraine.

5. Snapp, S., Grabowski, P., Chikowo, R., Smith, A., Anders, E., Sirrine, D. and Bekunda, M. (2018), Maize yield and profitability tradeoffs with social, human and environmental performance: is sustainable intensification feasible? Agricultural Systems, vol. 162, pp. 77-88. https://doi.org/10.1016/j.agsy.2018.01.012.

6. Sandhu, H., Scialabba, N., Warner, C., Behzadnejad, F., Keohane, K., Houston, R. and Fujiwara, D. (2020), Evaluating the holistic costs and benefits of corn production systems in Minnesota, US. Scientific Reports, vol. 10(1), pp. 1-12. https://doi.org/10.1038/s41598-020-60826-5.

7. Berzsenyi, Z., Győrffy, B. and Lap, D. (2000), Effect of crop rotation and fertilisation on maize and wheat yields and yield stability in a long-term experiment. European Journal of Agronomy, vol. 13(2-3), pp. 225-244. https://doi.org/10.1016/S1161-0301(00)00076-9.

8. Theriault, V., Smale, M. and Haider, H. (2018), Economic incentives to use fertilizer on maize under differing agro-ecological conditions in Burkina Faso. Food Security, vol. 10(5), pp. 1263-1277. https://doi.org/10.1007/s12571-018-0842-z.

9. Bykin, A. V., Bykina, N., Bordyuzha, N. and Ivanytska, A. (2019), The economic efficiency of the fertilizers application under agricultural crops for different soil tillage. Scientific journal «Crop and Soil Science», vol. 10(2), pp.62-69. https://doi.org/10.31548/agr2019.02.062.

10. Mahmood, F., Khan, I., Ashraf, U., Shahzad, T., Hussain, S., Shahid, M. and Ullah, S. (2017), Effects of organic and inorganic manures on maize and their residual impact on soil physico-chemical properties. Journal of Soil Science and Plant Nutrition, vol. 17(1), pp. 22-32. http://doi.org/10.4067/S071895162017005000002. 


\section{Agricultural and Resource Economics: International Scientific E-Journal}

http://are-journal.com

11. Jjagwe, J., Chelimo, K., Karungi, J., Komakech, A. and Lederer, J. (2020), Comparative performance of organic fertilizers in maize (Zea mays L.) growth, yield, $\begin{array}{llll}\text { and economic } & \text { results. }\end{array}$ https://doi.org/10.3390/agronomy10010069.

12. Poruțiu, A., Arion, F., Mureșan, I., Fărcaș, R., Sălăgean, T. and Moldovan, L. (2016), Economic optimization of the fertilization system on corn crops on a representative soil in the Transylvanian plain. Bulletin of University of Agricultural Sciences and Veterinary Medicine Cluj-Napoca. Horticulture, vol. 73(1), pp. 52-58. https://doi.org/10.15835/buasvmcn-hort:11601.

13. Adamtey N., Musyoka M., Zundel C. et al. (2016), Productivity, profitability and partial nutrient balance in maize-based conventional and organic farming systems in Kenya. Agriculture, Ecosystems \& Environment, vol. 235, pp. 61-79. https://doi.org/10.1016/j.agee.2016.10.001.

14. Uzoh, I. M., Igwe, C., Okebalama, C. B. and Babalola, O. O. (2019), Legume-maize rotation effect on maize productivity and soil fertility parameters under selected agronomic practices in a sandy loam soil. Scientific Reports, no. 9. 8539. https://doi.org/10.1038/s41598-019-43679-5.

15. Demidenko, O., Shapoval, I., Boyko, P. and Velichko, V. (2018), Productivity parameters and phytomass structure of rotary crop rotations of the Forest-Steppe of Ukraine. Bulletin of Agrarian Science, no. 5, pp. 54-62. https://doi.org/10.31073/agrovisnyk201805-09.

16. Diallo, L., Qing-jun, C., Zhen-ming, Y., Jin-hu, C. and Dafaalla, T. I. M. (2016), Effects of various doses of mineral fertilizers (NPKS and Urea) on yield and economic profitability of new varieties of Zea mays L. in Faranah, Guinea. Journal of Northeast Agricultural University, vol. 23(1), pp. 1-8. https://doi.org/10.1016/S10068104(16)30025-3.

17. Jarecki, M., Grant, B., Smith, W., Deen, B., Drury, C., Vander Zaag, A. and Wagner-Riddle, C. (2018), Long-term trends in corn yields and soil carbon under diversified crop rotations. Journal of environmental quality, vol. 47(4), pp. 635-643. https://doi.org/10.2134/jeq2017.08.0317.

18. DSTU 7863: 2015. Soil quality. Determination of light hydrolysis nitrogen by the Cornfield method. [Valid from 2016-07-01], available at: http://online.budstandart.com/ua/catalog/doc-page.html?id_doc=62745.

19. DSTU 4405:2005. Soil quality. Determination of mobile compounds of phosphorus and potassium by the method of Kirsanov in the modification of NSC ISSAR. [Valid from 2006-07-01], available at: http://online.budstandart.com/ua/catalog/doc-page?id_doc=60252.

20. DSTU 4732: 2007. Soil quality. Methods for determination of labile organic matter. [Valid from 2008-01-01], available at: http://online.budstandart.com/ua/catalog/doc-page.html?id_doc=72886.

21. DSTU 4731: 2007. Soil quality. Methods for determination of water-soluble organic matter. [Valid from 2008-01-01], available at: http://online.budstandart.com/ua/catalog/doc-page?id_doc=56400. 
22. Ushkarenko, V. O., $\quad$ Vozhehova, R. A., $\quad$ Holoborod'ko, S. P. $\quad$ and Kokovikhin, S. V. (2013), Statystychnyy analiz rezul'tativ pol'ovykh doslidiv u zemlerobstvi [Statistical analysis of the results of field experiments in agriculture], Aylant, Kherson, Ukraine.

23. Kachmar, O., Vavrynovych, O., Dubytska, A., Dubytsky, O. and Shcherba, M. (2019), Influence of fertilizer systems on the dynamics of unstable humic substances in short-rotation crop rotations. Bulletin of Lviv National Agrarian University. Agronomy, no. 23, pp. 234-237. https://doi.org/10.31734/agronomy2019.01.234.

Citation:

Стиль-ДСТУ:

Стасів О., Качмар О., Вавринович О., Арабська К. Еколого-економічна ефективність вирощування кукурудзи на зерно в короткоротаційних сівозмінах Західного регіону. Agricultural and Resource Economics. 2021. Vol. 7. No. 2. Pp. 182-199. https://doi.org/10.51599/are.2021.07.02.10.

Style-APA:

Stasiv, O., Kachmar, O., Vavrynovych, O. and Arabska, E. (2021), Ecological and economic efficiency of growing maize for grain in short-rotation cultivation of the Western region. Agricultural and Resource Economics, vol. 7, no. 2, pp. 182199. https://doi.org/10.51599/are.2021.07.02.10. 